\title{
HIGHER ORDER CORRELATIONS IN COMPUTED PARTICLE DISTRIBUTIONS
}

\author{
H. Hawenteld, W. HeRnuanssfeld ayo R. H. Millek \\ Stanford Linear Accelerutor Center. Stanford Uniterstly. Stonfard. $C_{A}$ 94909
}

\begin{abstract}
The rms emittances calculated for beam distributions uaing computer simulations are frequently dominated by higher order eberrations. Thus there are subtentid opes aress in the phese spece plots. It has long been oberrved that the rme enittance is not an invariant to beam manipulations. The uoul emittance calculation removes the correlation betweed tcanawere displactment and tranoverse momentum. In this papet, we explore the possibility of defining bigher ofder correlations that can be re moved from the distribution to mult in a lower limit to the realizable emittance. The intent is that by inserting the correcl combinations of linear lenses at the proper paition, the beam may recombine in a way that cancels the eftects of some bigher order forces. An example might be the ood-linear transverse space charge forces which cause a beam to spread. If the beam is then refoeused so that the same non-lineur forces reverse the inward velocitien, the resulting phuse spuce diatribution may teaconably approximate the original distribution. The approach to finding the location and strength of the proper leos to optimize the truniported beam is based on work by Bruct Carlsten of Los Alunes Vetional Laboratory.
\end{abstract}

\section{INTRODUCTION}

Iire motwation for this paper come from the studien' by the autbon of a photocsthade injector aystem for a lineas ac. celerator jateoded to be used for a Free Electron Leer (EEL). This work was dope in colleboration witb Shefield et al., of Los Alamos Yational Luboratory and followed along the lines of the system reported by Fracer. ${ }^{2}$

The methods used mere reported by Henerfeld.' and in. volved the extensive uve of a Particle in Cell (PIC) program called MASK." Similar methods have been employed by Jones and Peter (4) using differeat prograrra. Their resulta, wbile dif. iering an detail. are substactialy connisteat witb the realts from MASk. The results generally do not sbow the very low emittance beeded for an FEL. ${ }^{\top}$ It is possible to carfully adjust the profram diegootics to malch the experimeatal cooditions and get

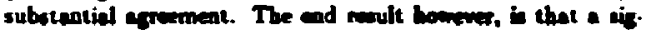
nifieant frection of the enithed chare mat be elianiated from consideration.

A different approuch has been followed by McBondd and by Carleten and Sberistd." They howe und vemicen of the code PARMELA w follow the bem throuth o beger wetion of the beginning of the secelerator thas i prectienl wies a fully diertromeratic PIC code. The significant conchuion of these utud-

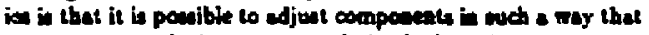
enittance promtb that occun maly is the hijectico procem can

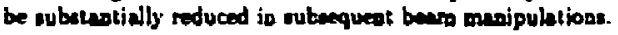

While most elatron beam ayotems are enituance dominated, the laver photocatbode is aspace charge dominated syotern. For

\footnotetext{
- Work rupported by the Department of Edery, cootract DEACo3-765F00515.
}

apece charge dominated systerns which have been studied for the application of intense bealy ion beams for Heavy Ion fusion. 11 has long been observed that rms emittance is not conscried "in Carloten bas gone one atep further and extablished a systerr. atic way to examine wources of emiltance growth and to design tystems, principally wolenoid lensex, to recover the ernitiance $" 1$ The design procens is endagous to inserting vextupole lenses at selected putitions in magnetic beam transport system The in. teut of the preaent atudy is to sp: fically teat Carlsten 's methad for a simple case of a short slug charge in a drift tube nult? a short colenoid lens to refocus the sam

\section{TRANSPORT SIMULATION}

The beam transpoit simulatiot was made using the PIC code MASK A short slug. 350 pucoseconds long. carpsing $10 S$ nanocoulombs, is injected into a drift tube at joo kel' The longlcudinal distribution of the slug is trapezoidal and the transverse distribution is for \& uniform beam Thus the problem fis the conditions for Carlsten's criteria lor "lir-ar" forces on the beam particles. Note however. that the radia' urces are not the samer on the ends of the slug as in the middle The intual conditions are for a perfectly parallel beam with ze : emitlance The in. jection conditions were deliberately chos: io be lon energs 10 avoid the genesation of transient fi fields at could complicate understanding.

A composition picture of the bunch as 11 traverses Ihrough the drift section is thown in Fig. 1 Note that only one bunch is in the problem at a time $A$ short solenoid lens is located wh its renter at $\mathbf{Z}=26,32$ and $36 \mathrm{~cm}$. respectively: for different ruas W'ith the nominal magnet ic field $\left(B_{0}\right)$. the focal lengih of the leas was found to be 22.2 centimeters.

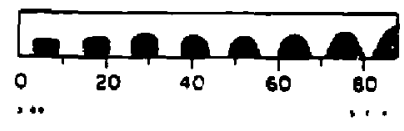

Fig. 1. Pericle densily plat from AsASh houring a slu: of eharge, entering from the lept, ressing through ofors: ing leas and continuing esuentially pardiel.

As the beam begins 10 expand traovernely; the wean farits ot the eads of the alus foil to lorce the outer particles away as fat a ocants ib the center of the slug. This results in the fan abaped diatribution thow $n$ in the first frame of Fig 2, which it localed at $Z=9 \mathrm{~cm}$. Tbe remaioiog frames of Fig. 2 are loceted alter the colenoid kens and are at $Z=30,56,60$. 75 . and $87 \mathrm{~cm}$., respectively. The focusing lens is becaled at $Z=26 \mathrm{~cm}$ for the results shown in Fig. 2 . Ellipses superimposed on the particle distributions are appropriale for the phese space ares and corcelation for etnittance given by

$$
\mathrm{ta}=4\left[\left(x^{2}\right)\left(x^{2}\right)-\left(x x^{\prime}\right)^{2}\right]^{1 / 2} / \mathrm{A} / \mathrm{A}
$$


The last two frames in Fig. 2 show some particles branching away from the main ensemble. These are particles that have crossed the axis because of their lack of space charge forces. Although these particles do not affect the emittance calculations significantly, they do signal the onset of what Carlsten ${ }^{11}$ calls $a_{\text {crit, }}$ where $a=1 / f, f=$ focal length, and $\alpha_{c r i t}$ is the focusing strength which begins to cause crossoters.
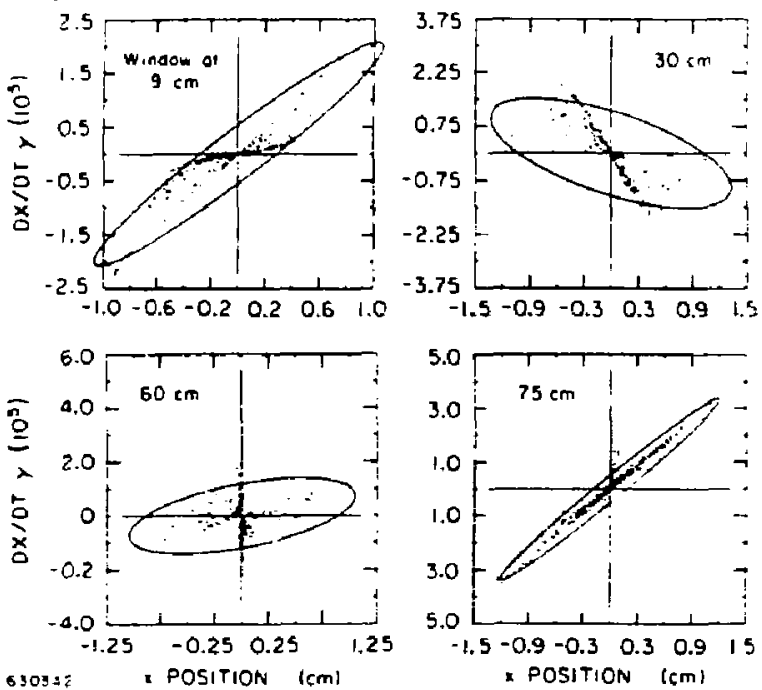

$28 \mathrm{~cm}$. This results in a prediction of $\alpha_{L}=0.068, a$ focal length $\mathrm{L}=15 \mathrm{~cm}$, compared to the physical value of 22.2 poted earluer

Having found that a reasonably precise location for the emit. tance minimum exists for a fixed magnetic field, $B_{0}$, it is intercst ing to try to vary the magnes to further reduce that minimum emittance. Accordingly, runs were made with $\mathrm{B}=\mathrm{B}_{\circ} \pm 5 \%$

Fig. 2. Phase space plots from MA 1 folloung the case with the center of the focusing lens at $Z=2 \mathrm{~cm}$

Figure 3 shows plots of emituance vs. $Z$ for three locations of the coil. It is notable that the minimum emittance is virtually the same for each of these curves. This is in afreement with Carlsten's conclusion that the emittance minimum can be pro. jected abitraily far away. There are, of course, limits as in this instance, the lens cannot be any stronger because of crossovers and cannot be much weaker and still have the beam reconverge at all. Another practical limit of these simulations is tbat it is Lifficult to expand the length of the drift tube and retain the same mesh resolution. Thus we have not explored the location of the emitrance minimum over a very wide range.

The emitlance minimum does not occur near a beam waist, as expected, but is in fact somewhat downstream as found here. The low part of the emiltance curve, plotted a a function of $Z$, all occurs after the beam wain. For the case of the center of ine wlenoid at $Z=28$, the weist is at $Z=56 \mathrm{~cm}$, which is very near the peak of the emitiance curve. This may be because, for ihe reasous given above, there is very little convergence for this seam so that the waist is very near the lens. The emittance minimurs for the cave of the center of the colenoid at $28 \mathrm{~cm}$, is at $2=75 \mathrm{~cm}$. The minimum emittance is expected to occur at a position z, mesured from the anter of the kns, if the focal strength of the lens is $\alpha_{l}=1 / \mathrm{f}$, such that ${ }^{31}$

$$
\alpha_{L}=2 \frac{z_{1}+z}{z^{2}},
$$

With the center of the solenaid at $Z=28 \mathrm{~cm}$, the distance from the lens to the location of the minimum emittance, $z$, is $47 \mathrm{~cm}$. The distance $z_{1}$ from the waist at $Z=0$ to the lens center is
A slighe, but perceptibly kower, minimum was found at $0.95 \mathrm{~B}_{0}$. as shown in Fig. 4. The cese for $1.05 \mathrm{~B}_{0}$, not shown, resulted in bigher emittance but was complicated by the crossover problem.

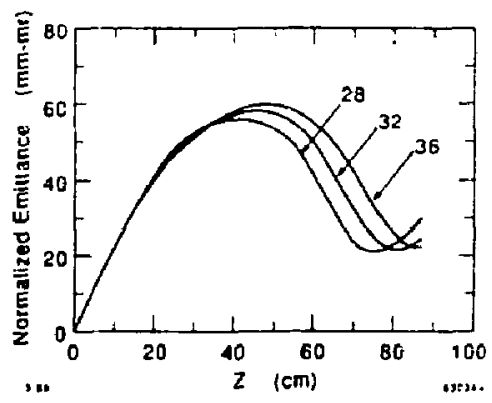

Fig. 9. Emittance vs. 2 for three locations of the facusing lens

\section{CONCLUSIONS}

The foregoing is a very preliminary look at some of the predictions of Cartsten's paper ${ }^{1]}$ in an attempt to find the logic in the disagreements between the methods of modeling. Qualitative apreerment was found, especially with the shape of thr 


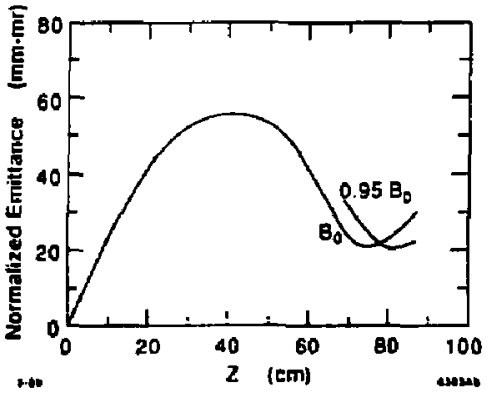

Fig. 1. Emtlance us. $Z$ for the focusing lens at $Z=$ $28 \mathrm{~cm}$ and two diference uniues far the magnefie field.

curve of emittance as a function of Z. Specific predictions of lens streagths and the location of the beam waist relative to the emitance minimum were not confirmed, but the cause for this has not beep determined. It could well be that the conditions of the test are not ideal.

\section{REFERENCES}

J. W. Herrmannsfeldt, R. Miller. and $\mathrm{H}$. Hanerfeld, Proc. BEAMS-88, Th Int. Conf. on High Pourer Part. Brams. eds., W. Bever and W'. Schmidt, Karistube, W'. Germany. July 1988.

2. J. S. Fruser, R. L. Sheffield, E, R. Gray, P. M. Giles. R. W. Springer, and V. A. Loebs, Photacathades in Ac. celerator Applications, IEEE Particle Arcelerator Confer. ence, Washington. D./.C., Mar 1967

3. H. Hanerfeid, W. Herrmannsfeldt. B. Lippmann, and R. Miller, Proc. Linear Accel. and Bcam Ophres lliark. shop, AlP Conf. Proc. No 17T, ed., C, Eminhizer, Sa:t Diego (1968).

A. A. Palevsky and A. T. Drobot. Proc. Sih Conf on Numerical Simulation of Plasmas. Northwesterti Init. Evanston. IL (1980).

5. M. E. Jones and $W$. Peter, IEEE Trass. Sucl So 32 . 1794 (1985).

6. M. E. Jopes and W. Peter. Proc. 6th int. Conf on Hight Power Beams, Kobe. Japan (1986).

7. C. W. Roberwod. Y. Y. Lau and H. P. Freund, Emulfonce Brighiness, Fre Electron Laser Bram Qualuty and thi Scaled Thermal Velocuty, to be published in Pros 1AJW Adranced Study Instifule, Pitlorhry; Scotland, July 19Ris. Plenum Press.

8. Kirk McDonald, Proc. Linear Accel and Beom Optics Workshop, AIP Conf. Proc. No. 177, ed., C. Emınhize: San Diego, CA (1988).

9. B. E. Carsten and R. L. Shefield, Proc. Ig8e Linear Aced! Conf, Williamsburg, YA, Oct. 1988

10. Kyoung Hahn and Lloyd Snith, LBL-2616T (Ortoler 1986) and Proc. IEEE Int Plasma Physics Conf. Buf. Wo. NY (May 1989).

11. B. E. Cartsten, Proc 10th Int. Fre-Electron Lostr Conf. Jerusdem. Istael (Augusi 19Es).

\section{DISCLAIMER}

This repon was prepared as an account of work sponsored by an agency of the Unted States Govemment. Neither the United States Govemment nop any agency thereof, nor any of thejemployees. makes any warranty, express or implied. of assumes any legal liabili1y of responsibility for the accuracy, completeness. Or usefulness of any information, appantus, product, or process diseloned, or represents that its use would not infringe privately owned nghts. Reference herein to any specific commercial product, process, or service by trade name, trademark. manufacturer, or ofherwise dow not neosurily constitute or umply its endorsement, recommendation, or fovoring by the Unitod States Government ar any agency thereof. The views and opiniops of authors expeessed berein do not necessurnly state of reflect those of the United States Governmeat of any azency thereof 